\title{
Morphological Aspect of the Midgut of Anopheles aquasalis (Curry, 1932) Insecta: Diptera
}

\author{
Aspecto Morfológico del Intestino Medio de Anopheles aquasalis (Curry, 1932) Insecta: Diptera
}

"Ferreira, M. A. P.; * Lima, J. B.; "Rocha, R. M. \& ****Pimenta, P. F. P.

FERREIRA, M. A. P.; LIMA, J. B.; ROCHA, R. M. \& PIMENTA, P. F. P. Morphological aspect of the midgut of Anopheles aquasalis (Curry, 1932) Insecta: Diptera. Int. J. Morphol.,26(3):577-582, 2008.

SUMMARY: The midgut of adult female Anopheles aquasalis presents a narrow anterior or thoracic region and a distensible posterior or abdominal region constituted by the epithelium formed by a cell layer whose apical portion presents microvilli and the basal portion, a basal labyrinth. The thoracic region revealed heterogeneous cellular staining affinity mainly by the presence of acidic components. The ultrastructural aspect showed columnar cells with the presence of the vesicle, mitochondria, endoplasmic reticulum and secreting cells. The abdominal region of the midgut revealed an irregular epithelium whose cells presented a basophilic cytoplasm and acidophil granules. It was also found secreting and/or basal cells with narrow cytoplasm. The ultrastructural observation of this region demonstrated cells with evident nucleus, endoplasmic reticulum and mitochondria. Larger vesicles and small granules were found distributed throughout the cytoplasm. The basal lamina that supports the epithelium presented a generally irregular aspect and the muscle fibers have longitudinal and circular organization and were found separating the epithelium from the haemocel. This study will contribute to analyses on the vector mosquito-parasite interaction mechanism in this specimen.

KEY WORDS: Anopheles aquasalis; Midgut; Mosquito; Ultrastructure.

\section{INTRODUCTION}

Most of the hematophagous insects present a midgut morphologically and physiologically divided into two or more parts (Reinhardt, 1976; Lehane \& Billingsley, 1996). The anterior or thoracic region is responsible for the absorption of sugar and the formation of a mucous material and the posterior or abdominal region is responsible for the absorption, synthesis, and secretion of digestive enzymes and the peritrophic matrix (Hecker \& Brun, 1975; Reinhardt; Hecker, 1977; Rudin \& Hecker, 1979; Lehane \& Billingsley; Park \& Shahabuddin, 2000).

The midgut of insects is in general constituted by a single cell layer whose apical portion is usually oriented to the organ lumen and the basal portion is supported by the basal lamina (Lehane \& Billingsley; Sherman, 1998). Different types of cells that make up the intestinal epithelium of insects have been described (Priester, 1971; Reinhardt; Hecker; Andriè \& Tramu, 1985; Glattli et al., 1987; Lehane \& Billingsley; Siden-Kiamos \& Louis, 2004). However, nothing is known about the epithelial organization of the midgut of Anopheles aquasalis. Thus, the present work aims to characterize the morphology of the midgut of Anopheles aquasalis, a natural vector of human malaria in the Amazon region.

\section{MATERIAL AND METHOD}

Mosquito Colony. Adult Anopheles aquasalis females were raised under standard insectary conditions, $28{ }^{\circ} \mathrm{C}$ with $80 \%$ relative humidity and photoperiod of $12 \mathrm{~h}$ dark to $12 \mathrm{~h}$ light. Adults were fed $10 \%$ glucose solution ad libitum, as described by Silva et al. (2006). Then, individual midguts were dissected and fixed for 3 hours in $2.5 \%$ glutaraldehyde solution in $0.1 \mathrm{M}$ sodium cacodylate buffer $\mathrm{pH} 7.2$ and processed as described below.

Light Microscopy. After fixation the samples were dehydrated in concentrated graded ethanol series, immersed

\footnotetext{
* Departamento de Histologia e Embriologia - CCB- Universidade Federal do Pará, Belém- PA, Brasil.

** Instituto de Pesquisa do Exército do Rio de Janeiro, Rio de Janeiro - RJ, Brasil.

${ }^{* * *}$ Laboratório de Entomologia Médica - Centro de Pesquisas René Rachou - FIOCRUZ, MG, Brasil.
} 
and included in historesin (Leica). Serial $2 \mu \mathrm{m}$ thick sections were stained with toluidine blue and Gomori's trichrome. The samples were examined and photographed with an Olympus photomicroscope.

Transmission Electron Microscopy. After fixation midgut fragments were post-fixed in $1 \%$ osmium tetroxide and $0.8 \%$ potassium ferricyanide in $0.1 \mathrm{M}$ sodium cacodylate $\mathrm{pH} 7.2$ for 1 hour, dehydrated in graded acetone series and embedded in Epon 812. Ultrathin sections were contrasted with uranyl acetate and lead citrate and analyzed by ZEISS EM 900 transmission electron microscopy.

\section{RESULTS}

The morphologic study of the thoracic region (Fig. 1) revealed a regular epithelium whose cells showed accentuated acidophily at the apical portion, where there
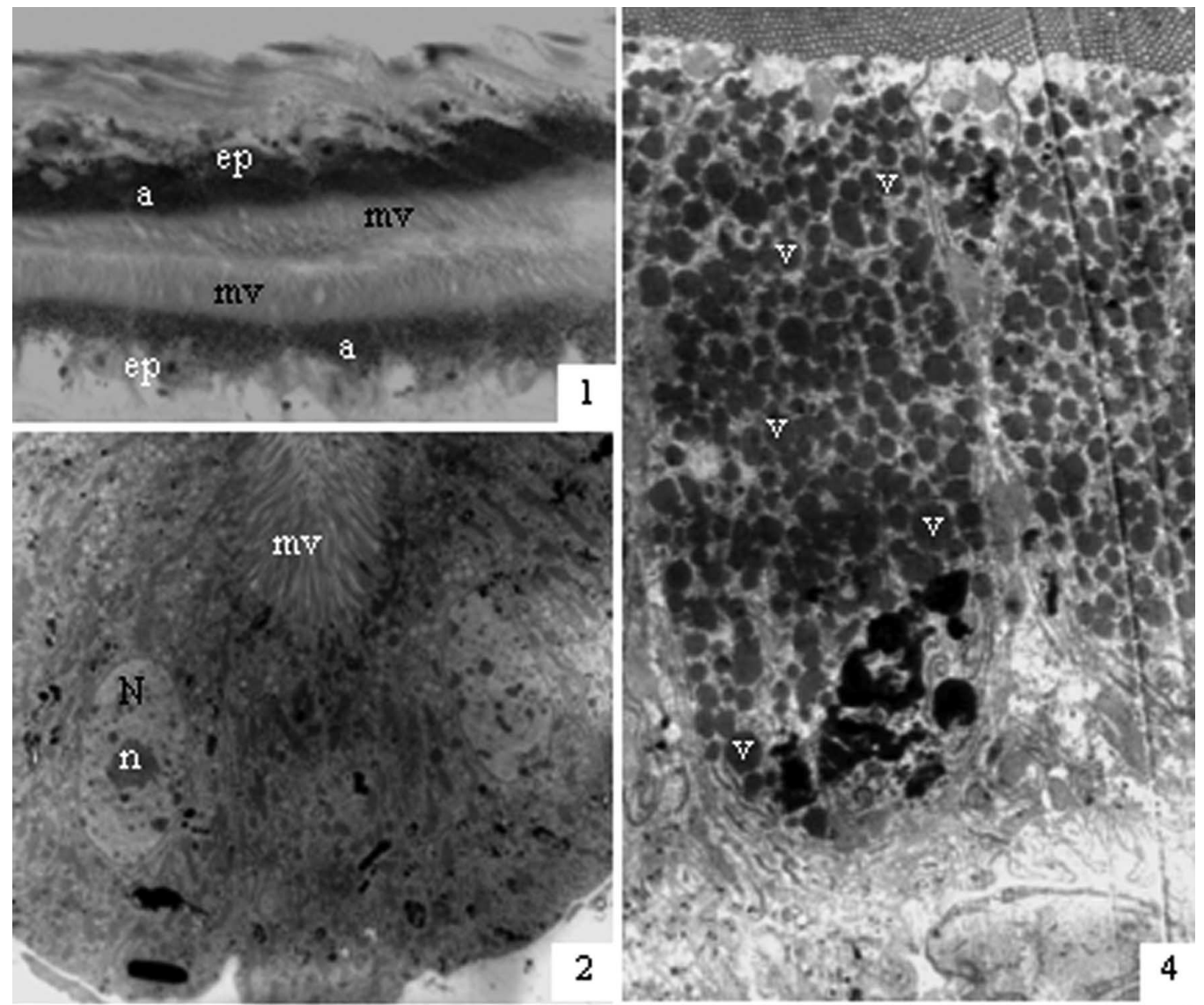

Figs. 1-5. Midgut thoracic region:

1. Epithelium (ep), columnar cells with microvilli (mv), granules acidophilis (a) in the apical area. Gomori's Trichrome stain. H-E. X400.

2. Eletronmicrograph of the columnar cells: microvilli (mv), nucleus (N) and nucleolus (n) X700.

3. Mitochondria $(\mathrm{m})$ and endoplasmic reticulum with linear (arrow) and spiral (s) organization.
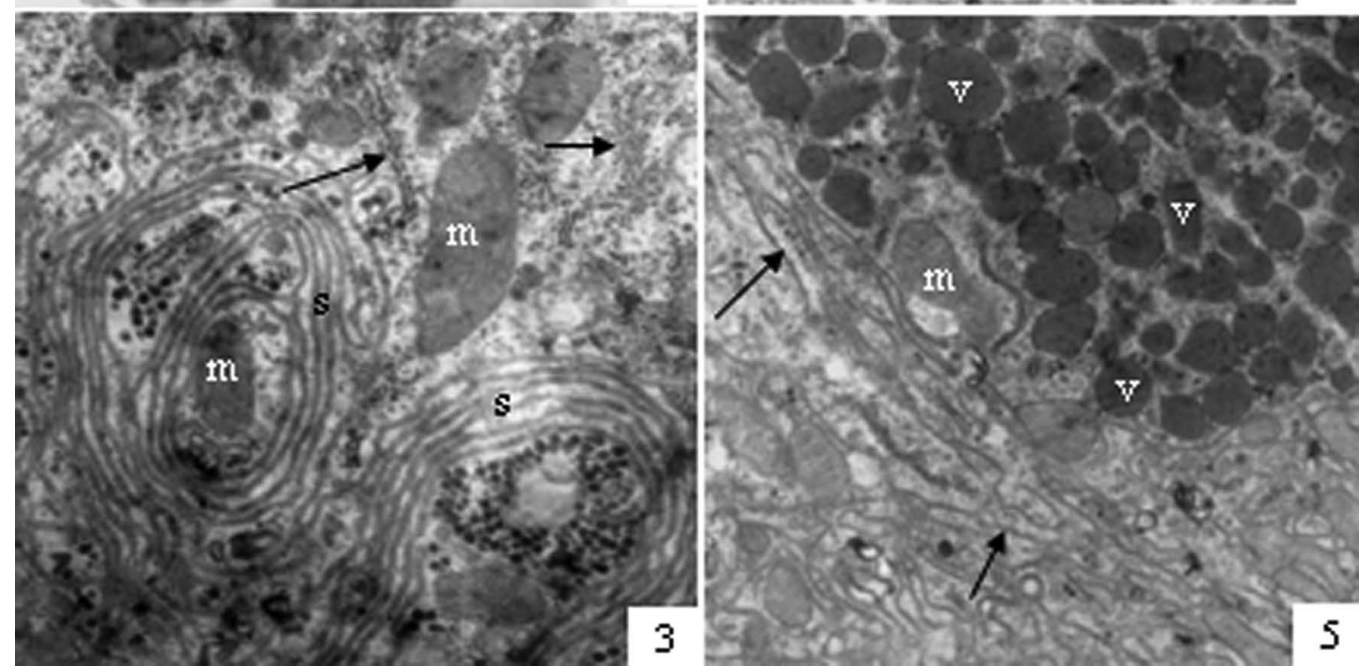
X12000.

4. Secreting cells: limited vesicles (v) for membrane with varied size X12000.

5. Detail of the secreting cells with endoplasmic reticulum linear (arrows), mitochondria $(\mathrm{m})$ and vesicles (v). X800. 
exists granulated material, in contrast with the basal portion of the cells. The epithelium ultrastructure in this region showed cells with elongated nuclei with loose chromatin and prominent nucleolus (Fig. 2). In the cytoplasm, it was possible to observe a great number of endoplasmic reticulum with spiral and linear organization and mitochondria (Fig. 3). It was also observed secreting cells (Figs. 4, 5) with cytoplasm filled with several electron dense vesicles limited by membrane. The basal area (Fig. 5) of these cells presented endoplasmic reticulum with linear organization.
The analysis of the abdominal region of the midgut showed cells with basophilic cytoplasm, nuclei and nucleoli, and granules in the apical portion (Fig. 6). Some atypical cells were observed projecting towards the hemocoele with the basal portion occupied by the round nucleus and a narrow cytoplasm that reaches the lumen (Fig. 7). The ultrastructural observation of this region revealed columnar cells with moderate electron density and rounded nucleus. The cytoplasm showed endoplasmic reticulum, mitochondria, vesicles with moderate electron
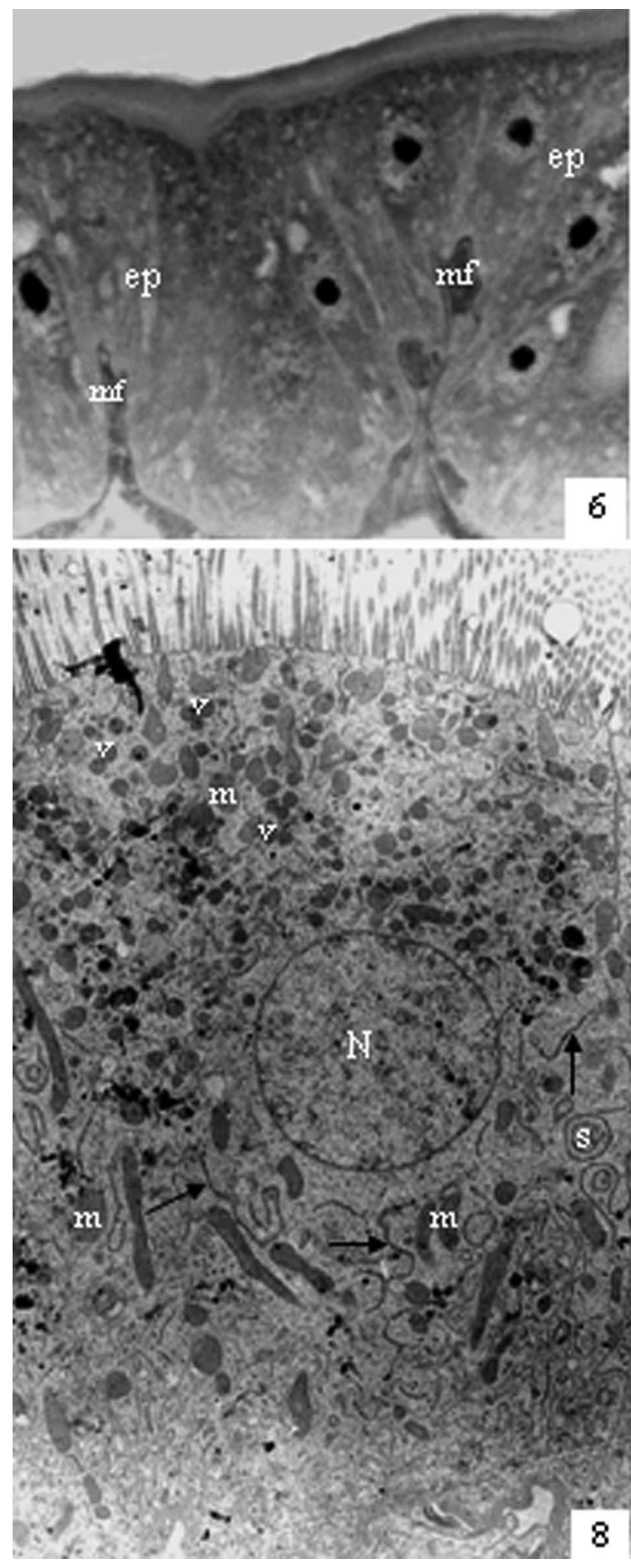
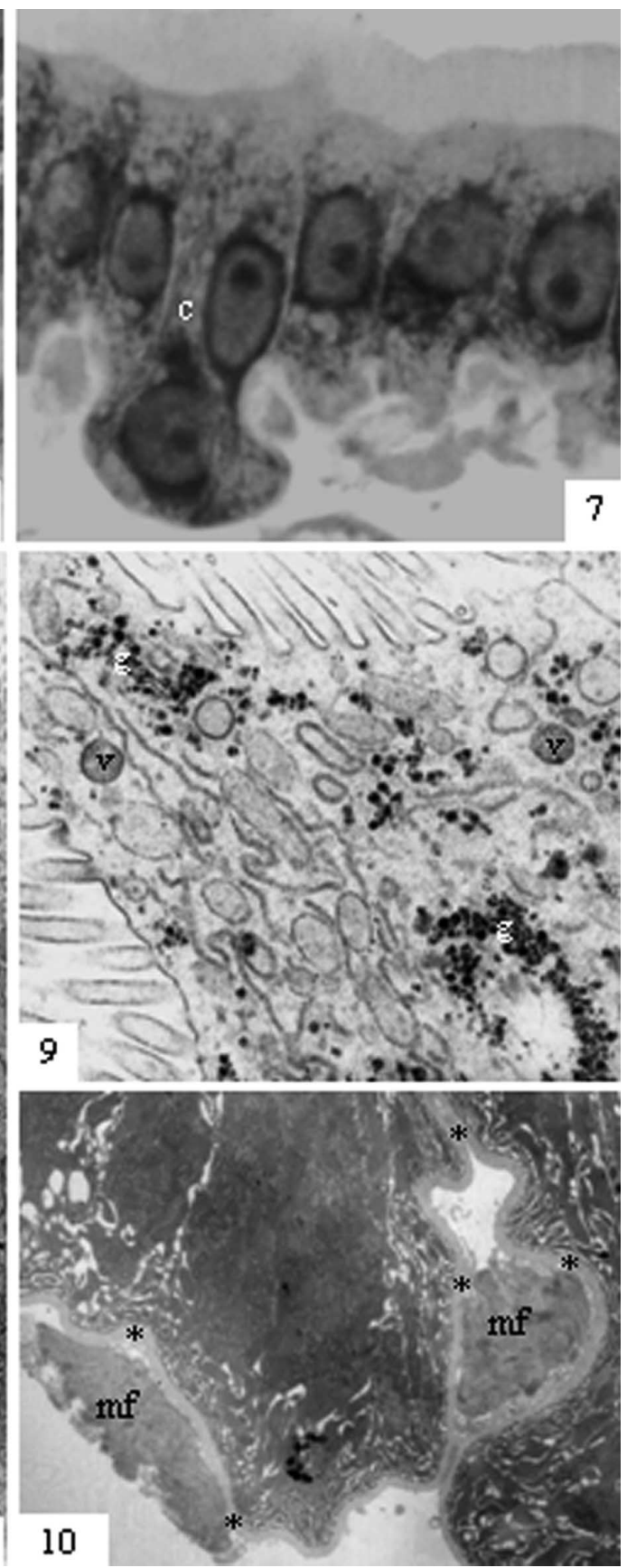

Figs. 6-10. Midgut - abdominal region:

6. Epithelium (ep) with basophil cytoplasm and muscle fibers (mf). Gomori's trichrome stain. X400.

7. Untypical cell with basal area projecting towards for the hemocoele. Toluidine blue. X400.

8. Electronmicrograph of columnar cells. Rounded nuclei $(\mathrm{N})$, mitochondria (m), vesicles (v), endoplasmic reticulum linear (arrow) and spiral (s). X600.

9. Detail of the apical surface of the cell with vesicles (v) and granules small (g). X25000.

10. The basal labyrinth with basal lamina (*) and below presence of the muscle fibers (mf). X5000. 
density and small isolated and grouped granules distributed in the cytoplasm (Figs. 8, 9). The basal portion of the cells was generally characterized by the presence of the basal labyrinth constituted by a pronounced irregularity of the membrane (Fig. 9). The basal lamina presented a generally thick, irregular, and continuous aspect. It was observed smooth muscle fibers in longitudinal and circular arrangements, separating the epithelium from the hemocoele (Fig. 10).

\section{DISCUSSION}

In most of the hematophagous insects studied, little importance has been attributed to the thoracic region, since it is only characterized as a blood passage tube towards the abdominal region and as not being actively involved in blood digestion. But we observed that this region showed cells with endoplasmic reticulum in cisternae and/or spiraled arrangements either associated to ribosomes or not and electron dense vesicles. The presence of these organelles has already been demonstrated by Hecker. Hecker et al. (1971) had already hypothesized that the formation of these spiraled arrangements could be found in three-to-four days-old mosquitoes. This region in Anopheles, depending on the species, produces mucus at different digestion times (Freyvogel \& Staubli, 1965). In the case of A. aquasalis, it is possible that vesicles in this region contain mucus, as histological findings demonstrate the presence of acid components. Schneider et al. (1986) reported the participation of the anterior midgut of $A$. stephensi in the absorption of blood components. Therefore, we could also suggest that the thoracic region may be involved in the synthesis and secretion of components for the abdominal region during feeding.

The abdominal region has been the most studied in insects in general for its being related to the synthesis and secretion of enzymes, and blood storage and digestion. In the case of vector mosquitoes, the parasite suffers modifications in this region, interacts with, and invades epithelial cells (Torii et al., 1992; Okuda et al., 2002; Gupta et al., 2005; SidenKiamos \& Louis), as is the case of A. aquasalis.

In A. aquasalis the observation of this region revealed columnar cells with moderate reactivity to staining. The ultrastructure analysis revealed presence of the rough endoplasmic reticulum around the nucleus. It is possible that this organization indicates the synthesis of protease before blood meal (Staubli et al., 1966), or a regulating mechanism of RNA transport from the nucleus to the cytoplasm (Reinhardt). We evidenced too mitochondria in large quantity and had a larger concentration in the apical region, it was suggested that it is necessary energy for the transport of substances through the membrane (Hecker et al.; Houk, 1977); some electron dense vesicles in the cytoplasm, Anopheles sp. has a large number of apical vesicles in the epithelial cells before blood feeding (Staubli et al.; Hecker), the content of these vesicles could represent precursors of the peritrophic matrix and of digestive enzymes that may be released by exocytose immediately after blood ingestion. In A. aegypti, Anopheles sp., these substances are synthesized, stored, and released during blood feeding and digestion (Freyvogel \& Staubli; Gander, 1968; Okuda et al.); and were observed small electron dense granules in the cytoplasm, which suggests the presence of glycogen. In Anopheles sp., the lipid and glycogen-like materials present in the epithelial cells before and during blood feeding digestion (Schneider et al.) supposed metamorphose reminiscent (Hecker). In C. quinquefasciatus, it is frequent the presence of glycogen agglomerates in the supra nuclear region of the epithelial cells (Okuda et al.).

In the abdominal region, we also found modified cell types with basal characteristic, but only under light microscopy. These cells presented a narrow cytoplasm and few basophils. However, due to their localization, we could attribute them a regenerative function responsible for the renovation of the epithelium, or yet, characterize them as endocrine.

In general, the basal portion of the epithelium could be characterized by the presence of the basal labyrinth. This aspect common to the diptera insects could be attributed to the transport of components (Lehane \& Billingsley). Supporting the epithelium was observed a basal lamina thickness and it is a consequence of good nutrition during the larval stage (Clements, 1992) which facilitates the transport of products between the intestine and the hemolymph (Reinhardt \& Hecker, 1973; Houk et al., 1980). On analyzing the intestinal epithelium of the midgut of $A$. aquasalis, cells in a cell death process were not observed. This process is apparently related to the bloodmeal (Okuda et al.), which was first observed in mosquitoes infected with Plasmodium sp., suggesting that this aspect is a response to a parasite invasion (Han et al., 2000; Zieler \& Dvorak, 2000; Gupta et al.). The morphologic characterization of the midgut of A. aquasalis led to the understanding of the organization of its components, which has enabled us to describe their specific characteristics. This will contribute to studies on the vector mosquito-parasite interaction mechanism in this specimen.

\section{ACKNOWLEDGEMENTS}

This work was supported by CNPq - Conselho Nacional de Desenvolvimento Científico e Tecnológico, PICDTUFPA/CAPES 
FERREIRA, M. A. P.; LIMA, J. B.; ROCHA, R. M. \& PIMENTA, P. F. P. Aspecto morfológico del intestino medio de Anopheles aquasalis (Curry, 1932) Insecta: Diptera. Int. J. Morphol.,26(3):577-582, 2008

RESUMEN: La sección media del intestino de la hembra de Anopheles aquasalis presenta una estrecha región anterior o toráxica y una región posterior o abdominal constituida por el epitelio formado por una camada de células cuya porción apical presenta microvilosidades y la porción basal presenta un laberinto basal. La región toráxica reveló afinidad de tintura celular principalmente para componentes acídicos. El aspecto ultra estructural mostró células columnares con la presencia de la vesícula, mitocondrias, retículo endoplasmático y células secretoras. La región abdominal del intestino medio reveló un epitelio irregular con células con citoplasma basófilo y gránulos acidófilos. También se encontraron células secretoras y/o basales con citoplasma estrecho. La observación ultra estructural de la región mostró células con núcleos, retículo endoplasmático y mitocondrias evidentes. Vesículas largas y gránulos pequeños fueron encontrados distribuidos por todo el citoplasma. La lámina basal que apoya el epitelio presentó un aspecto irregular y las fibras musculares tienen organización longitudinal y circular y separan el epitelio del hemocele. Este estudio contribuirá al analisis del mecanismo de interacción entre el mosquito y el parásito en este espécimen.

PALABRAS CLAVE: Anopheles aquasalis; Intestino medio; Mosquito; Ultraestrutura.

\section{REFERENCES}

Andriè, J. C. \& Tramu, G. Ultrastructural and immunohistochemical study of endocrine cells in the midgut of the cockroach Blaberus craniffer (insect, dictyoptera). Cell Tissue Res., 240:323-32, 1985.

Clements, A. N. Development, Nutrition and Reproduction. In: The Biology of Mosquitoes. London, Chapman \& Hall, 1992. p. 509.

Freyvogel, T. A. \& Staubli, W. The formation of the perithrofic membrane in Culicidae. Acta Trop., 22:11847, 1965.

Gander, E. On histochemistry and histology of the midintestine of the Aedes aegypti and Anopheles stephensi reference to the blood digestion. Acta Trop., 25(2):133-175, 1968.

Glattli, E.; Rudin, W. \& Hecker, H. Immunoelectron microscopic demonstration of pancreatic polypeptide in midgut epithelium of hematophagous dipterans. $J$. Histochem. Cytochem. 35(8):891-6, 1987.

Gupta, L.; Kumar, S.; Han, Y. S.; Pimenta, P.F. \& BarillasMury, C. Midgut epithelial responses of different mosquito-Plasmodium combinations: the actin cone zipper repair mechanism in Aedes aegypti. PNAS, 102(11):4010$5,2005$.

Han, Y. S.; Thompson, J.; Kafatos, F. C. \& Barillas-Mury, C. Molecular interactions between Anopheles stephensi midgut cells and Plasmodium berghei: the time bomb theory of ookinete invasion of mosquitoes. EMBO J. 19(22):1-11, 2000.
Hecker, H. Structure and function of midgut epithelial cells in culicidae mosquitoes (insecta, diptera). Cell Tissue Res., 184:321-4, 1977.

Hecker, H. \& Brun. R. Morphometric differences in midgut epithelial cells between strains of female Aedes aegypti L. (insecta, diptera). Cell Tissue Res., 159: 91-9, 1975.

Hecker, H.; Freyvogel, T.A.; Briegel, H. \& Steiger, R. Ultrastructural differentiation of the midgut epithelium in female Aedes aegypti L. (insecta, diptera) imagines. Acta Trop., 28(2): 80-104, 1971.

Houk, E. Midgut ultrastructure of Culex Tarsalis (diptera: culicidae) before and after a bloodmeal. Tissue Cell, 9(1):103-18, 1977.

Houk, E. J.; Chiles, R. E. \& Hardy, J. L. Unique midgut basal lamina in the mosquito Aedes dorsalis (MEIGEN) (Insecta, diptera). Int. J. Insect. Morphol. Embryol., 9:161-4, 1980.

Lehane, M. J. \& Billingsley, P. F. Structure and ultrastructure of the insect midgut. In: Biology of the Insect Midgut. Chapman \& Hall, 1996. p. 486.

Okuda, K.; de Souza Caroci, A.; Ribolla, P. E. M.; de Bianchi, A. G. \& Bijovsky, A. T. Functional morphology of adult female Culex quinquefasciatus midgut during blood digestion. Tissue Cell. 34(3):210-9, 2002.

Park, S. S. \& Shahabuddin, M. Structural organization of posterior midgut muscles in mosquitoes Aedes aegypti and Anopheles gambiae. J. Struct. Biology, 129:30-7, 2000. 
Priester, W. De. Ultrastructure of the midgut epithelial cells in the fly Calliphora erythrocephala. J. Ultrastruc. Res., 36:783-805, 1971.

Reinhardt, C. A. Ultrastructural comparison of the midgut epithelia of fleas with different feeding behavior pattern (Xenopsylla cheopis, Echidnophaga gallinacea, Tunga penetrans, Siphonaptera, Pulicidae). Acta Trop., 33 (2): 105-32, 1976.

Reinhardt, C. \& Hecker, H. Structure and function of the basal lamina and of the cell junctions in the midgut epithelium (stomach) of female Aedes aegypti L. (insecta: diptera). Acta Trop., 30 (3):213-35, 1973.

Rudin, W. \& Hecker, H. Functional morphology of the midgut of Aedes aegypti L. (insecta: diptera) during blood digestion. Cell Tissue Res., 200:193-203, 1979.

Schneider, M.; Rudin, W. \& Hecker, H. Absorption and transport of radioactive tracers in the midgut of the malaria mosquito Anopheles stephensi. J. Ultrastruct. Mol. Struct. Res., 97:50-63, 1986.

Siden-Kiamos, I. \& Louis, C. Interactions between malaria parasites and their mosquito host in the midgut. Insect Biochem. Mol. Biol., 34: 679-85, 2004.

Silva, A. N. M.; Santos, C. C. B.; Lacerda, R. N.; Souza, R. T. L.; Rosa, E. P. S.; Galiza, D.; Sucupira, I.; Povoa, M.M.; Conn, J. Laboratory Colonization of Anopheles aquasalis (Diptera: Culicidae). J. Med. Entomology, 43(1):107-9, 2006.

Sherman, I. W. (Ed.) Malaria Parasite Biology, Pathogenesis and Protection. Washington: ASM Press, 1998. p. 575.

Staubli, W., Freyvogel, T. A. \& Suter, J. Structural modification of the endoplasmic epithelial cells of mosquitoes in relation to blood intake. J. Microsc., 85:189-204, 1966.

Torii, M., Nakamura, K. I., Sieber, K. P., Miller, L. H. \& Aikawa, M. Penetration of the mosquito (Aedes aegypti) midgut wall by the ookinetes of Plasmodium gallinaceum. J. Protozool., 39 (4):449-54, 1992.

Zieler, H. \& Dvorak, J. A. Invasion in vitro of mosquito midgut cells by the malaria parasite proceeds by a conserved mechanism and results in death of the invaded midgut cells. PNAS. 97(21):11516-21, 2000.
Correspondence to:

Prof. Maria Auxiliadora P. Ferreira

Departamento de Histologia e Embriologia - CCB

Universidade Federal do Pará

Rua Augusto Corrêa - 01

Guamá

CEP 66075-900.

Belém- Pará

BRASIL

Fax: 0055 (91)3201-7601

E-mail: auxi@ufpa.br

Received: 19-02-2008

Accepted: 28-07-2008 